\title{
Recent patent applications in metabolomics
}

\begin{tabular}{|c|c|c|c|c|c|}
\hline Patent Number & Description & Assignee & Inventor & $\begin{array}{l}\text { Priority } \\
\text { application } \\
\text { date }\end{array}$ & $\begin{array}{c}\text { Publication } \\
\text { date }\end{array}$ \\
\hline US 20120143622 & $\begin{array}{l}\text { A method for preventing an adverse drug event asso- } \\
\text { ciated with drug-drug interaction, drug-substance } \\
\text { interaction, drug-gene interaction, drug-phenotype } \\
\text { interaction and substance-factor interaction, involv- } \\
\text { ing displaying warning of a victim-culprit interaction } \\
\text { and level of severity on a graphical user interface. }\end{array}$ & $\begin{array}{l}\text { Genelex (Seattle, WA, } \\
\text { USA) }\end{array}$ & $\begin{array}{l}\text { Coleman H, } \\
\text { Oesterheld J, } \\
\text { Patterson R }\end{array}$ & 2/14/2007 & 6/7/2012 \\
\hline CN 102478563 & $\begin{array}{l}\text { A method for researching metabolic differences } \\
\text { between transgenic rice and non-transgenic rice, } \\
\text { involving analyzing rice seed extracted by a liquid } \\
\text { phase chromatography-mass spectrometry technol- } \\
\text { ogy for obtaining a rice metabolic profile spectrum. }\end{array}$ & $\begin{array}{l}\text { Dalian Institute of } \\
\text { Chemical Physics, } \\
\text { Chinese Academy of } \\
\text { Science (Dalian, China) }\end{array}$ & $\begin{array}{l}\text { Chang Y, Lu X, Xu G, } \\
\text { Zhao C, Zhao Y, Zhou J }\end{array}$ & $11 / 25 / 2010$ & $5 / 30 / 2012$ \\
\hline $\begin{array}{l}\text { US } 20120119080 \text {, } \\
\text { WO } 2012068217\end{array}$ & $\begin{array}{l}\text { A method for establishing an unbiased model using } \\
\text { the metabolic profile, phenotypic profile and trait } \\
\text { profile of two groups of plants, involving separating } \\
\text { extracting metabolites from two groups of plants } \\
\text { by chromatography to generate a data set and com- } \\
\text { paring to another data set generated using mass } \\
\text { spectrometry. }\end{array}$ & $\begin{array}{l}\text { Pioneer Hi-Bred } \\
\text { (Johnston, IA, USA) }\end{array}$ & $\begin{array}{l}\text { Hazabroek J, Janni J, } \\
\text { Lightner J }\end{array}$ & $11 / 17 / 2010$ & $\begin{array}{l}5 / 17 / 2012 \\
5 / 24 / 2012\end{array}$ \\
\hline WO 2012061105 & $\begin{array}{l}\text { Human HCT116 colorectal cancer cells that com- } \\
\text { prise IDH1R132H and wild-type isocitrate dehy- } \\
\text { drogenase } 1(\text { IDH1) alleles, which can be used to } \\
\text { determine the effect of IDH1R132H on cell biology, } \\
\text { tumorigenesis and cellular metabolic profiles. }\end{array}$ & $\begin{array}{l}\text { Duke University } \\
\text { (Durham, NC, USA) }\end{array}$ & $\begin{array}{l}\text { Bigner D, Duncan C, } \\
\text { Yan H }\end{array}$ & $10 / 25 / 2010$ & $5 / 10 / 2012$ \\
\hline WO 2012051463 & $\begin{array}{l}\text { A method of identifying the presence or level of kid- } \\
\text { ney disease in a subject, involving determining the } \\
\text { level of organic acid, e.g., glycolic acid, comparing } \\
\text { the level of organic acid with a reference level and } \\
\text { identifying kidney disease. }\end{array}$ & $\begin{array}{l}\text { Regents of the University } \\
\text { of California (Oakland, } \\
\text { CA, USA) }\end{array}$ & Naviaux RK, Sharma K & $10 / 14 / 2010$ & 4/19/2012 \\
\hline US 20120040383 & $\begin{array}{l}\text { A method of diagnosing colorectal cancer in a sub- } \\
\text { ject involving obtaining a sample from the subject, } \\
\text { determining a metabolite profile for the subject's } \\
\text { sample by measuring the amount of at least one } \\
\text { metabolite biomarker, comparing the subject's } \\
\text { metabolite profile to a healthy control metabolite } \\
\text { profile for the same metabolite biomarkers, and } \\
\text { identifying differences between the subject's } \\
\text { metabolite profile and the healthy control metabo- } \\
\text { lite profile. }\end{array}$ & Jia W, Qiu Y & Jia W, Qiu Y & $8 / 12 / 2010$ & $2 / 16 / 2012$ \\
\hline IN 200900390 & $\begin{array}{l}\text { A method of extraction, separation and characteriza- } \\
\text { tion of metabolite biomarkers for identification of } \\
\text { diseases in human plasma using a metabolomics } \\
\text { approach. }\end{array}$ & $\begin{array}{l}\text { Avesthagen (Bangalore, } \\
\text { India) }\end{array}$ & $\begin{array}{l}\text { Jain R, Patel VM, } \\
\text { Shinde M }\end{array}$ & 2/24/2009 & 2/3/2012 \\
\hline CN 102324001 & $\begin{array}{l}\text { A method for predicting cancer based on high- } \\
\text { performance liquid chromatography/mass spec- } \\
\text { trometry metabolomics data analysis, involving } \\
\text { performing ultra performance liquid chromatography } \\
\text { (UPLC)-MS detecting technology to obtain data, } \\
\text { extracting data, aligning and normalizing the data, } \\
\text { subjecting the data to multidimensional statistical } \\
\text { analysis process, differentiating the metabolite, } \\
\text { establishing orthogonal projections to latent } \\
\text { structures-discriminant analysis cooperation model } \\
\text { and verifying the model. }\end{array}$ & $\begin{array}{l}\text { Shanghai Julei } \\
\text { Biotechnology Co. } \\
\text { (Shanghai) }\end{array}$ & Liu $Y$ & $11 / 15 / 2010$ & $1 / 18 / 2012$ \\
\hline US 20110307180 & $\begin{array}{l}\text { A verification and confirmation method for analyz- } \\
\text { ing metabolomics data, involving determining an } \\
\text { identity confidence measure associated with the } \\
\text { selected metabolites by comparing data sources } \\
\text { with respect to the selected metabolites. }\end{array}$ & $\begin{array}{l}\text { Metabolon (Durham, NC, } \\
\text { USA) }\end{array}$ & $\begin{array}{l}\text { Alexander DC, } \\
\text { Barrett TH, DeHaven CD, } \\
\text { Tanikella S }\end{array}$ & $8 / 8 / 2005$ & $12 / 15 / 2011$ \\
\hline
\end{tabular}

Source: Thomson Scientific Search Service. The status of each application is slightly different from country to country. For further details, contact Thomson Scientific, 1800 Diagonal Road, Suite 250, Alexandria, Virginia 22314, USA. Tel: 1 (800) 337-9368 (http://www.thomson.com/scientific). 